\title{
Beyond Method: The Rise of Reflective Teaching
}

\author{
Jalil Fat'hi (Corresponding author) \\ Allameh Tabataba'i University, Tehran, Iran \\ E-mail: jfathi13@yahoo.com \\ Fouad Behzadpour \\ Tarbiat Modares University, Tehran, Iran \\ E-mail: Fouad.behzadpour@gmail.com
}

Received: May 23, $2011 \quad$ Accepted: June 23, $2011 \quad$ doi:10.5539/ijel.v1n2p241

\begin{abstract}
Some recent changes in ELT and teacher education has led to the shift of attention and orientation from positivistic views of language teaching towards a process-oriented constructivist views in which learning is viewed as an active process where learners reflect upon their current and past knowledge and experiences to generate new ideas and concepts. One major ramification of this dramatic shift was the demise of method and the emergence of post method condition. In this paper it is proposed that in the quest for something in lieu of method, reflective teaching has been considered as a solution to the problems teachers face in the 'beyond method' era. Then, it is revealed that reflective teaching has its own drawbacks and deficiencies. And finally, the origin and the components of teacher reflection have been briefly touched upon.
\end{abstract}

Keywords: Teacher education, Postivistic view, Constructivist, Post method condition, Reflective teaching, Teacher reflection

\section{Background}

As far as pedagogy is concerned there have been lots of changes over the second half of the twentieth century in second/foreign language teaching and teacher education, and more specifically from 1990 onward (Akbari, 2005; Crandall, 2000; Freeman, 2002; Kumaravadivelu, 2001; Pica, 2000). These changes epitomize a shift from a positivist-oriented perspective to a constructivist-oriented one and "a shift from transmission, product-oriented theories to constructivist, process-oriented theories of learning, teaching, and teacher learning" has been particularly conspicuous (Crandall, 2000, pp. 34-35). Brown (2000) maintains that constructivism sprang into being as a dominant paradigm only in the last part of the twentieth century. Similarly, he points out that constructivists conceive of reality as socially-constructed and it is now an accepted practice to hold various constructions of knowledge. Thus, this new conception of knowledge puts the act of learning in an entirely different context. As Cunningham (2001) explains, "constructivism views learning as an active process where learners reflect upon their current and past knowledge and experiences to generate new ideas and concepts" (p. 2). As a consequence, "a shift to a constructivist perspective of teaching and teacher learning makes teachers a primary source of knowledge about teaching" (Crandall, 2000, p. 35), and this, in turn, has paved the road for democratic approaches of teaching to come to the fore. As Akbari (2005) puts it, new avenues are being probed and language teaching is no longer seen as a mere technocratic enterprise. He sums it up "the shift in paradigm is due to the change of scope observed in modern language teaching literature and a concern for disciplines and issues previously regarded as irrelevant by both practitioners and theoreticians" (p. 14).

\section{Beyond Method}

Apparently such a dramatic shift is bound to have some ramifications. As Akbari (2005) and Pica (2000) explicate the post method condition is typical of such transitions and is one of the concepts that echo the above-mentioned changes in language teaching. The recurring discontent with the notion of method and the technicist model of teacher education gave rise to postmethod (Kumaravadivelu, 2001). The top-down criticism leveled against the bogeyman of method entails its being too prescriptive in the sense that teachers don't seem to have any voice in what to teach and how to teach it. And this is equally true about the roles of teachers and 
learners (Crandall, 2000; Kumaravadivelu, 1994; Pennycook, 1989; Richards and Rodgers, 2002). In comparison with the traditional teacher education which "views teachers as passive recipients of transmitted knowledge rather than active participants in the construction of meaning ... and which does not take into account the thinking or decision-making of teachers" (Crandall, 2000, p. 35), the postmethod condition is a practice-driven construct which calls into question the traditional conceptualization of teachers as a channel of received knowledge (Kumaravadivelu, 1994, 2003a); it raises serious questions regarding the traditional dichotomy between theorizers and practitioners with a view to empowering teachers whereby they can "theorize what they practice and practice what they theorize" (Kumaravadivelu, 2001; p. 545). In this era "it is teachers who have to act as mediators between theory and practice, between the domain of disciplinary research and pedagogy" (Widdowson, 1990, p. 22). As Kumaravadivelu (2001) holds all pedagogy is a politically-charged process in which particularity is embedded in active awareness of local conditions. Within the pedagogy of particularity as one of the constituents of the postmethod debate, teachers are entrusted with "observing their teaching acts, evaluating their outcomes, identifying problems, finding solutions, and trying them out to see once again what works and what does not" (p. 539). In fact, teacher autonomy is a key component of postmethod in a way that "it can be seen as defining the heart of postmethod pedagogy" (Kumaravadivelu, 2001, p. 548). To summarize, and borrowing on Akbari (2005):

The postmethod condition is a more democratic approach to language teaching profession since it assigns a voice to practitioners and respects the type of knowledge they possess. In addition, it is a libratory move which gives teachers more autonomy and confidence in the decisions they make in their classes (p. 5).

In a nutshell, within this framework teachers play a pivotal role in language classes and the exponential increase and eagerness in taking teachers into account as the focal point of education is manifest in the strikingly increasing number of journal articles dealing with language teacher education (Clarke, 1994). Since postmethod problematizes the traditional concept of method, there is a need for alternatives that can help teachers materialize the objectives set by postmethod.

\section{The Rise of Reflective Teaching}

In the quest for something in lieu of method, the eclectic approach was put forth by practitioners, which set in motion a discord between theoreticians and practitioners. Amidst this clash between the two camps, reflective teaching was introduced because it promised to be the solution to the dilemma (Akbari, 2007). There have been many qualitative or case studies on reflective practices whose findings have been infused with enthusiasm on the part of trainee teachers and lecturers in favor of reflective approaches (Cornford, 2002). One reason lies in the fact that teachers don't find much in conventional approaches in terms of ways to tackle their practical problems (Richards and Lockhart, 1999), and reflective teaching has emerged as a response to the call for a substitute for the concept of method. According to Gimenez (1999) the heyday of reflection in teacher education was the 90's and it continues to be significantly dominant so that today nobody engaging in the field of teacher education can deny its ubiquitous role in this field. In effect, reflection has been of great importance and has received noticeable attention in teacher education and teachers' educational development in recent years and is a key component of teacher development (Clarke and Otaky, 2006; Griffiths, 2000; Jay and Johnson, 2002; Johnson and Johnson, 1999; Richards, 2000; Vieira and Marques, 2002). "Reflection has become an integral part of teacher education" (Jay and Johnson, 2002, p. 73), and as Tabachnick and Zeichner (2002) put it, "there is not a single teacher educator who would say that he or she is not concerned about preparing teachers who are reflective" (p. 13).

Reflection, in the words of a layman, “... simply means thinking about something," but for some, "it is a well-defined and crafted practice that carries very specific meaning and associated action" (Loughran, 2002, p. 33). To begin with, reflective teaching "at a very general level involves thinking about one's teaching" and the cogitation involved "can take place before the event of teaching and manifest itself as planning, after the event as evaluation and simultaneous to the teaching as reflection in action involving adjustments to or accommodation of some of the contingencies which arise" (Parker, 1997, p. 8). In defining reflective teaching, however, one important point should be kept in mind and that is there doesn't seem to be any clear-cut definition with respect to the concept of reflective teaching. In turn this has bred a situation where various approaches have found their way into teacher education programs (Akbari, 2007; Cornford, 2002; Farrell, 1998, 2004; Freese, 1999; Ixer, 1999; Jay and Johnson, 2002; Pollard, 2002), which has led to a kind of ambiguity in this area, and as Gimenez (1999) puts it, “... the meanings of reflection are not clear cut...there is such a variety of uses for this word that it is imperative to specify what one really means when referring to reflection" (pp. 1-2). This confusing multitude of definitions and interpretations has been the focus of some researchers. Akbari (2007) draws attention to the discrepancy between the notion of reflection defined and intended by Dewey who is referred to, 
in most of the works in the literature of reflective teaching as the pioneer of introducing the reflective practice to education (Akbari, 2007; Farrell, 2004; Hillier, 2005; Pacheco, 2005), with that of Schon, another influential authority on reflective teaching (Griffiths, 2000; Ixer, 1999; Tsui, 2003). His argument pivots on the fact that reflection for Dewey "is equal to professionalism and knowledge is based on scientific approaches", whereas Schon believes that "reflection is an intuitive, personal, non-rational activity ... and knowledge is the direct result of practice" (p. 5). It is noteworthy that this distinction is of paramount significance since the literature seems to have taken it for granted that Dewey and Schon concurred on the notion of reflection. Despite the existence of an abundant number of definitions for the term, Jay and Johnson (2002) provide a somehow comprehensive definition of reflective teaching proposed by a group of teaching assistants who engaged in teaching the reflective seminars in their teacher education program:

Reflection is a process, both individual and collaborative, involving experience and uncertainty. It is comprised of identifying questions and key elements of a matter that has emerged as significant, then taking one's thought into dialogue with oneself and with others. One evaluates insights gained from that process with reference to (1) additional perspectives, (2) one's own values, experiences, and beliefs, and (3) the larger context within which the questions are raised. Through reflection, one reaches newfound clarity, on which one bases changes in action or disposition. New questions naturally arise, and the process spirals onward (p. 76).

It is interesting to note that reflection has gained momentum over the years in mainstream education despite all the above-mentioned confusion in relation to its definition. It has gained in popularity in almost all facets of teacher education encompassing adult and vocational education (Cornford, 2002), and it is now reaching epidemic proportions in other professions such as nursing and social work (Ixer, 1999). Reflective teaching has contributed to furthering the field of education as a whole in a number of ways. In this connection Farrell (2004) states:

Teachers can become more empowered decision makers, engaging in systematic reflections of their work by thinking, writing, and talking about their teaching; observing the acts of their own and others' teaching; and by gauging the impact of their teaching on their students' learning. In these ways, teachers can begin to locate themselves within their profession and start to take more responsibility for shaping their practice. This I call reflective teaching (pp. 5-6).

Reflective practice, as mentioned above, has remarkably influenced the whole field of education and the ESL/EFL context is no exception (Farrell, 1999a). Cunningham (2001) while referring to reflective practice as an "evolving" notion and maintaining that "there are [both] benefits and challenges to implementing reflective practice in ESL," mentions four benefits of flexibility, practicality, professionalism, and sustainability to this practice (p. 2). Along the same lines Pacheco (2005) claims that "through reflection ESL/EFL professionals can react, examine and evaluate their teaching to make decisions on necessary changes to improve attitudes, beliefs and teaching practices." (p. 2). Reflection-driven exploration of teaching can have many merits. It can facilitate the process of gaining better insights into teaching from both a theoretical and a practical perspective; it can enrich teaching and learning processes; it can act as a springboard for self-appraisal and consequently is extremely crucial when it comes to professional development (Richards and Lockhart, 1999).

Cornford (2002) drawing on Kuhn (1970) elucidates that the success of any paradigm in replacing another is contingent upon its superiority to existing or competing paradigms. However, if it fails to prove to be superior, then it won't be acknowledged by knowledgeable practitioners or at best its proven parts will be absorbed into other theory or paradigms. However, the lack of any empirical methods for the assessment of new approaches or paradigms renders it very difficult to prove its practical effectiveness. With this end in mind, only a few studies have been published to look into the practical effectiveness of reflective teaching. He also asserts that while it is self-evident that reflective approaches are theoretically rich, the hitch lies in their inability to translate into practice. In this regard, there isn't any empirical evidence that reflective teaching approaches have culminated in better teaching or learning for novice teachers (ibid). In the same vein, Akbari (2007) states that teacher educators are instrumental in enhancing reflective teaching practices in the classroom; moreover, one way to empower teachers and place them on equal footing with their academic counterparts is through reflection. He further argues that though research indicates that reflection can bring about an increase in teacher job satisfaction, an improvement in interpersonal relationship with colleagues and students, and an improvement in teachers' sense of self-efficacy, there is very little evidence that reflection will necessarily lead to higher students' achievements and better teacher performance. He notes that if teachers engage in reflective practice, it doesn't necessarily mean that students will achieve better results (ibid). Therefore, one might come to the conclusion that in spite of all the praise, there is no real hard evidence to link reflective teaching to actual learning outcomes and improved teacher practice and this, in its own right, can be considered a big flaw to this approach. 


\section{Origins of reflection and reflective teaching}

When it comes to the notion of reflection, historically speaking, John Dewy, "generally recognized as the most renowned American educator of the twentieth century" (Apple and Teitelbaum, 2001, p. 177), is considered the ground-breaker, who blazed a trail in the field of (teacher) education (Griffiths, 2000; Ixer, 1999; Jay and Johnson, 2002; Osterman and Kottkamp, 2004; Zeichner and Liston, 1996) and, in effect, "his distinction of 'routinized' and 'reflective' teaching is fundamental to the conception of professional development through reflection" (pollard, 2002, p. 4). A more profound look at the literature on reflective teaching, however, reveals that the idea of reflection has run the whole gamut of all disciplines to the effect that it can be traced back to the works of Descartes ( see Fendler, 2003), Kant, Wittgenstein, and the pragmatists Pierce and Popper; it is even rooted in Plato's Meno (Ixer, 1999). One can see a plethora of writings about reflection under the veil of self-analysis discussions in the works of Aristotle, Plato, and Socrates, who established 'educational thinking' philosophy (Cornford, 2002). Despite all these scholars' contributions to the development of this view, Dewey's works on reflective practice seem to be more relevant. As a pragmatist, Dewey introduced three different types of action: impulsive action, routine action, and reflective action; 'trial and error' features impulsive action, and routine action has 'authority,' 'tradition,' 'preconception,' and 'prejudice' as its indispensable components; the two actions have inactive and tactless behavior in common (Griffiths, 2000; Pollard et al., 2006). Reflective action, on the other hand, is in principle "the active, persistent and careful consideration of any belief or supposed form of knowledge in the light of the grounds that support it and the further conclusions to which it tends" (Dewey, 1933, p. 9, cited in Jay and Johnson, 2002, p. 74). Dewey's other ideas on reflective practice will be more dealt with in the relevant parts of this literature review. In language teacher education, reflective teaching has been put forward as a way out of the teachers' predicament and as a counteraction against the influences of "bureaucracy, centralization, and control" in which "teachers are seen simply as deliverers of a fixed curriculum" and are not "valued as reflective professionals who frame and re-frame problems and test out their interpretations and solutions" (Johnstone, 2006, p. 661). It can be regarded as a corollary of the postmethod condition (Kumaravadivelu, 1994, 2001, 2003b, 2005; Prabhu, 1990), which acts as "an empowerment and motivational process because it responds to basic human needs for competence, autonomy, and relatedness" and allows "individuals to assume greater responsibility for their own performance and learning" (Osterman and Kottkamp, 2004, p. 189). Fendler (2003) points out four trends as underlying streams that have been, to a great extent, conducive to the recognition of reflection: a) Cartesian rationality, which assumes that in reflection "self-awareness will provide knowledge and understanding about teaching" (p. 17), b) John Dewey's how we think, which was discussed above, c) Schon's professional reflection, which is "generally understood to be artistic and practiced based as opposed to positivistic and science based" (p. 19), and d) feminist anti-establishment interventions. Citing Akbari (2007), "Reflection on knowledge generation mechanisms and subverting those mechanisms to give more voice to women, or more feminine approaches, can be viewed as a force behind the rise of reflective movement in education" (p. 4). Some scholars believe that the cornerstone of reflective teaching and thinking critically originated from critical thinking (Cornford, 2002; Hillier, 2005). According to Jackson (2006), critical thinking "implies that we are open to all aspects, and willing to see issues from a multitude of views, always questioning and challenging the current state" (p. 3). Along similar lines Brookfield (1993) believes that it is quite possible to liberate ourselves form the confinements of our classroom by "questioning and then replacing or reframing an assumption which is accepted as representing dominant common sense by a majority" (p. 66, cited in Hillier, 2005, p. 14). Ronald Schon's ideas and oeuvre on reflective teaching have contributed a lot to the development and expansion of reflection (Farrell, 2004; Reed, Davis, and Nyabanyaba, 2002; Stanley, 1998; Zeichner \& Liston, 1996). Reflection-in-action includes visions, understandings and awareness teachers capture in the moment of teaching; reflection-on-action includes considerations, interpretations, deliberations and thoughts given to what happened in the classroom in the moment of teaching (Reed, Davis, and Nyabanyaba, 2002). As Farrell (1998) puts it, "Reflection-in-action is concerned with thinking about what we are doing ... Reflection-on-action deals with thinking back on what we have done to discover how our knowing-in-action may have contributed to an unexpected action" (p. 12). For Stanley, "Such reflective thinking and examination either during or after the fact can lead to greater awareness on classroom teachers' part in relation to their knowledge-in-action, or the theories, ideas, metaphors, and images they use as criteria for decision making in their teaching practice" (1998, p. 685). It is also supposed that reflective practice might have been derived from some religious beliefs. Cornford (2002), for instance, believes that "Reflective teaching is very much in accordance with Protestant religious values where truth is seen as emerging from within, from a revelation ... In adult education ... there appears to be a high number of ministers or former ministers associated with the Protestant churches who are writers about or supporters of reflective practices" (pp. 229-230). 


\section{The delusive nature of the conception of reflection}

The literature pertaining to the idea of reflection has witnessed a loose and fuzzy treatment of the concept, and there are varied definitions dealing with this conception galore (El-Dib, 2007; Farrell, 1999b, 2001, 2004; Freese, 1999). The following definitions, explanations, and realizations of reflection, reflective teaching and reflective practitioner are provided to put this issue into perspective and to prove that reflection really "means so many things to so many people" (Russell, 1993, p. 144, cited in Reed, Davis, \& Nyabanyaba, 2002, p. 256). According to Hoover (1994) reflection "is a carefully planned set of experiences that foster a sensitivity to ways of looking at and talking about previously unarticulated beliefs concerning teaching" (p. 84, cited in Farrell, 2001, p. 36). Hoover seems to believe that reflection is a systematic practice that can be learned from the past experiences one has had (Farrell, 2001). Hoover's understanding of reflection is very much similar to that of Gebhard who believes that "Reflection includes thoughtful persistent consideration of beliefs or practices" (Gebhard, 2005, p. 4). Van Manen (1991, cited in El-Dib, 2007) defines reflection as "the process by which teachers engage in aspects of critical thinking such as careful deliberation and analysis, making choices, and reaching decisions about a course of action related to teaching" (p. 25). While referring to the fact that "not all thinking about teaching constitutes reflective teaching," Zeichner and Liston (1996) elucidate the contrast between reflective teaching and technical teaching believing that "if a teacher never questions the goals and the values that guide his or her work, the context in which he or she teaches, or never examines his or her assumptions, then ... this individual is not engaged in reflective teaching" (p. 1). LaBoskey (1994) provides a definition of reflection which is somehow similar to that of Dewey (1910). She believes that reflective thinking is a "careful reconsideration of a teacher's beliefs and actions in light of information from current theory and practice, from feedback from the particular context, and from speculation as to the moral and ethical consequences of their results" (LaBoskey, 1994, p. 9, cited in LaBoskey, 1997, p. 153). She further argues that one cannot draw a border line between reflective and nonreflective individuals. Her position concurs with that of Akbari (2007) that "teachers have always been reflecting on what they have been doing in their classes"... and it is "impossible to imagine a context in which we have human interaction on a cognitive level and no reflection going on" (p. 9). Again, citing LaBoskey (1997), it is the extent, level, and depth of reflection that can distinguish "Alert Novices", i.e. those who reflect more, from "Commonsense Thinkers", i.e. those who reflect less. Commitment to a "passionate creed" or a zealous ideology which gives the green light to the learners' votes and removes injustice constitutes a key feature of reflective practice in LaBoskey's words. Drawing on Schon's ideas, Clarke (1994) believes that a reflective teacher a) is inquisitive about some dimension of his/her teaching practice, b) 'frames' the dimension in light of the specific aspects of his/her classroom teaching, c) 'reframes' that dimension according to his/her background knowledge or past experience and d) tries to arrive at a means or strategy for future practices (cited in Farrell, 2004, p. 19). Farrell $(1998,2004)$ has summarized five major approaches to reflective teaching. First of all, he refers to 'technical rationality,' in which reflection is defined as the efficient exploitation of 'technical knowledge' and 'cognitive aspects' of teaching practice by beginning teachers. The second and third types, reflection-in-action and reflection-on-action, were explained before. The fourth type of reflection Farrell refers to is reflection-for-action; it could be considered as a new kind of reflection added to Schon's reflection-in-action and reflection-on-action. This concept of reflection is "proactive in nature" and through developing certain procedures "teachers can prepare for the future by using knowledge from what happened during class and what they reflected on after class" (Farrell, 2004, p. 31). And finally he refers to 'action research' as an integral part of reflective teaching. Action research is a vehicle via which teachers become researchers of their own; they can be autonomous and have their own voice in order to cogitate on the particularities of their troublesome situations (Burns, 2005; Farrell, 2004; Zeichner and Liston, 1996). Farrell (2004) identifies seven general phases of the reflective practice in action research as diagnosing the problematic situation, finding a plan to examine the predicament identified at first, talking to colleagues and reading the related literature to know what is there regarding that particular situation, employing different procedures such as observation and diary keeping to come up with more tangible data, interpreting and evaluating the obtained data, reframing the predicament and trying out the solutions that have been arrived at, and keeping on the same procedure to know whether those solutions have been consequential or not. Dewey (1933) establishes seven major characteristics of the reflective practice:

Reflective teaching implies an active concern with aims and consequences, as well as means and technical efficiency; reflective teaching is applied in a cyclical or spiraling process, in which teachers monitor, evaluate and revise their own practice continuously; reflective teaching requires competence in methods of evidence-based classroom enquiry, to support the progressive development of higher standards of teaching; reflective teaching requires attitudes of open-mindedness, responsibility and wholeheartedness; 
reflective teaching is based on teacher judgment, informed by evidence-based enquiry and insights from other research; reflective teaching, professional learning and personal fulfillment are enhanced through collaboration and dialogue with colleagues; reflective teaching enables teachers to creatively mediate externally developed frameworks for teaching and learning (cited in Pollard et al., 2006, pp. 14 \& 15).

To Dewey's credit, a reflective practitioner holds three frames of mind: open-mindedness, responsibility and wholeheartedness. Open-mindedness refers to the teachers' willingness to question the status quo and to take into account various alternatives and possibilities and, thus, to give a second thought to their and others' beliefs, attitudes and preconceptions. To be responsible means to be aware of the reverberations of any course of action we take in the practice setting and to take into consideration the ways in which our students might be affected morally, socially and psychologically. Wholeheartedness, which has been also mentioned by LaBoskey (1997), refers to teachers being zealous, pledged and devoted (Farrell, 2004; Pollard et al., 2006).

\section{Models/frameworks of reflection and reflective teaching}

As far as the models and frameworks of reflection and reflective teaching are concerned, a variety of dominant models have been mentioned in the literature. Zeichner and Liston (1996) propose a model for reflection which includes reflection phases rather than reflection content. Their model consists of the following five dimensions: a) rapid reflection which "is likely to be personal and private ... in rapid reflection, teachers reflect immediately and automatically while they are acting," b) repair which "is still reflection-in-action, but here there is a quick pause for thought," c) review which "is interpersonal and collegial, and can happen at any time during or after the teacher's work day," d) research in which "the teachers' thinking and observation becomes more systematic and sharply focused around particular issues. It could be regarded as a more systematic reflection-on-action over a period of time" and e) retheorizing and research in which "reflection is more abstract and rigorous than in the other dimensions ... Here, while teachers critically examine their practical theories, they also consider these theories in light of public academic theories" (pp. 45-46). Under the nomenclature of a 'framework for teachers' reflectivity,' Stanley (1998) presents a model including five levels. In the first phase, 'engaging with reflection,' he talks about teachers' awareness of reflection. He believes that "When basic personal, professional, and contextual factors are stable and teachers are curious about learning the process of reflecting on their teaching, they can engage with reflection" (p. 686). He thinks that such an engagement would undoubtedly need to be supported by perpetual involvement and allegiance to the reflective practice. Permanent professional development and suitable contextual parameters are the sine qua non for engaging with reflection. In the second phase called 'thinking reflectively,' he presumes that "many teachers' initial reaction to reflection is simply to think back on a classroom situation and describe what happened and how they felt about it" (p. 686). He believes that reflection can be regarded as an ability that should be learned and mastered during the teaching process. Then he tries to say that in order for reflective teaching to be practiced spontaneously, it should be exercised a lot in different ways. In this phase, called 'using reflection,' he assumes that 'When teachers have understood what reflection is and how to think reflectively, they can use it as a tool. Just as in learning any new skill, there is a phase of experimentation and joy in seeing how many different shapes reflection can take and when, how, and with whom it can be done" (p. 687). In this phase teachers try to find and explore the actions that are commensurate with their context. In the next phase, i.e., 'sustaining reflection,' Stanley refers to different problems teachers confront while trying to practice reflection. He considers both critical and affective factors in reflective teaching that might hinder teacher reflectivity. And finally in the fifth phase which is 'practicing reflection,' he refers to the practical aspects of reflective teaching as an indispensable part of teacher reflectivity. Another model for different levels of reflection (Farrell, 2004) is the one given by Van Manen (1991). In his model Van Manen looks at reflection as a three-dimensional phenomenon. His reflection levels resemble Shon's reflective in action and reflective on action; besides, it takes into consideration reflection for action. His reflection for action, or 'anticipatory reflection,' "allows a teacher to plan, decide a course of action, and anticipate future consequences of the actions". Van Manen's 'active or interactive reflection' "allows a teacher to make immediate decisions during class as events unfold". And in the final stage, i.e., 'recollective reflection,' a teacher is allowed to "make sense of past experiences and give new, deeper insight into the meaning of those experiences" (cited in Farrell, 2004, p. 20). Day (1993), on the other hand, looks at the levels of reflection from another angle (Farrell, 2004). He features his three reflection levels as a) action or technical rationality which "is the level of a teacher's actions in the classroom and his/her observable behaviours", b) conceptual that "is the theoretical level which includes the theories behind the teacher's behaviours in level 1", and c) ethical, critical, or dialectical level which "is related to the role of the wider community in influencing a teacher's theories and beliefs (level 2) and practices, actions and behaviours (level 1)" (cited in Farrell, 2004, p. 34 ). Pachecho (2005), 
citing Pickett (1996, p. 1), provides five components of critical reflection probed by Ross (1990) and Spraks-Langer and Colton (1991). These components are mainly based on Schon's conceptions of this practice. They are as follows: identifying a problem, tackling the problem by comparing it with other similar contexts and considering its special context, evaluating and reevaluating the problem to find solutions, dealing with the problem to know about the results of the resultant resolutions, and "examining the intended and unintended consequences of an implemented solution and reevaluating the solution by determining whether the consequences are desirable or not" (p. 3). In 2002, Jay and Johnson proposed a typology for reflective teaching which seems to be more comprehensive and elaborate compared to the previous ones. Their typology includes descriptive, comparative, and critical reflection. Descriptive reflection refers to the identification, description and recognition of the problem to be reflected on. Comparative reflection involves "thinking about the matter for reflection from a number of different frames or perspectives" (p. 78). In this dimension a reflective teacher tries to know about others' ideas and checks other alternatives which might have some discrepancies with his/her own points of view. Critical reflection "involves teachers looking at all the different perspectives of a situation or problem and at all of the players involved: teachers, students, the school, and the community" (Farrell, 2004, p. 22). In this dimension of reflection, "By taking in the broader context of schooling, reflective practitioners come to see themselves as agents of change, capable of understanding not only what is, but also working to create what should be" (Jay and Johnson, 2002, p. 79). The last model proposed for reflective teaching dealt with in this study is that of Farrell (2004). After taking into consideration different models of reflection, he comes up with a model of his own. His model consists of five stages: a) teachers can embark on the reflective practice by going through keeping diaries, keeping teaching portfolios, discussing with peers, and observing other teachers' classrooms, b) a clear set of rules and regulations should be established for each and ever activity so that they could serve all participants, c) planning for four time phases in the reflective practice. The four phases include: 1) individual time which is the time each teacher allots to reflection, and it differs from individual to individual. In group discussions and works, however, it is of paramount significance for every individual teacher to make it clear how much time he or she can devote to the reflective practice, 2) activity time which is the amount of time allocated for the different activities mentioned above, 3) development time which is the amount of time each individual has to spend in order to master higher levels of reflection which, again, varies in different individuals, 4) reflection time which refers to the time spent in group discussions and is two fold: "the first involves how often and for how long a period they want to meet as group dedicated to reflective practice. The second aspect of time impacts pairs and groups of teachers: How much time within the group will be devoted to reflection itself?" (p. 44), d) reflective teachers should not only have a kind of individual reflection but also try to keep contact with others and to keep themselves update about what is going on in the relevant literature on teaching, reflection, and related practices, and e) since becoming involved in reflection can be considered a fundamental change in the teaching practice, the affective climate of the group discussion is very crucial to the efficiency and success of the group, hence providing a low-anxious context for group discussions.

\section{Components of reflection}

Despite all the controversy and lack of consensus regarding these components, the literature, in fact, provided the researcher with a rich and somehow comprehensive account of such components. The components of the reflection can be presented as follows:

\subsection{Focus on the learner}

From a 'developmentalist tradition' perspective of reflective teaching, students are the focus of reflection in the reflective practice. According to Zeichner and Liston (1996), this tradition "emphasizes reflection about students, their cultural and linguistic backgrounds, thinking and understandings, their interests, and their developmental readiness for particular tasks" (p. 57). The components which are worth reflecting on with respect to the learner include students' learning strategies, their cognitive and learning styles, their preferences, their affective factors, and their abilities (Hillier, 2005; Pacheco, 2005; Pollard et al., 2006; Richards and Lockhart, 1999; Richards and Farrell, 2005). Such elements have been categorized under the 'affective' factor in the questionnaire under study in this research.

\subsection{Focus on the teacher}

Unfortunately, while students have always been the focal point in any educational system, poor teachers have been ignored to a great extent. It is not a common practice to talk about teacher anxiety, teachers' different teaching styles, and teachers' affective factors. This point becomes more evident in the reflective context. As Akbari (2007) states, "Teachers' personality, and more specifically their affective make up, can influence their tendency to get involved in reflection and will affect their reaction to their to their own image resulting from 
reflection" (p. 10). Teachers' background, their system of values and beliefs, and the way they look at their practice are among other factors that should be scrutinized in any account of reflective practice components (Akbari, 2007; Hillier, 2005; Pollard et al., 2006; Richards and Lockhart, 1999; Stanley, 1998; Zeichner and Liston, 1996). Elements related to the teachers' affective factors have been labeled 'metacognitive' in the questionnaire under development.

\subsection{Focus on practical aspects}

Practical aspects of reflection here refer to the different tools, ways and procedures used and undertaken by teachers to fulfill this practice. Different ways and tools have been mentioned in the literature for this purpose, and one can see some consistency in this regard. Different tools/procedures for the reflective practice include 'journal writing,' 'lesson reports,' 'surveys and questionnaires,' 'audio and video recordings,' 'observation,' 'action research,' 'teaching portfolios,' 'group discussions,' 'analyzing critical incidents' (Farrell, 2004; Murphy, 2001; Richards \& Lockhart, 1999; Richards and Farrell, 2005). In this study, however, doing action research, for example, has been categorized under the 'cognitive development' of a reflective practitioner. A complete list of such tools and procedures has been included in the item pool developed by the researcher.

\subsection{Focus on teachers' cognitive development}

It is obvious that a reflective teacher, in his/her mission to fulfil different levels of reflection, should pay attention to his/her professional development as a teacher. Doing small-scale classroom research projects, attending the conferences and workshops related to one's field of study, and reading the literature will help him/her a lot in this domain (Farrell, 2004; Richards \& Farrell, 2005). In this study, such parameters have been grouped under the 'cognitive' factor in the instrument.

\subsection{Focus on critical/contextual aspects}

Another important factor discussed in the literature on reflection refers to the critical aspects of this practice. In some of the models reviewed earlier, Jay and Johnson (2002) and Day (1993) for example, had this aspect as one of the reflective levels in their models. Bartlett (1997) believes that reflection has got a two fold meaning. The first one, he writes, is a personal one which is related to a teacher's intellectuality and his/her practice. The other one, he states, "explores consciously the relationship (which may be a part of unconscious knowledge) between individual teaching actions and the purposes of education in society" (p. 205). This he calls 'critical reflection'. Based on the 'social reconstructionist tradition' of reflective teaching, "instruction is embedded within institutional, cultural, and political contexts ... and these contexts both affect what we do and are affected but what we do" (Zeichner \& Liston, 1996, p. 59). This view of reflection has incorporated the moral and ethical aspects as well (Farrell, 2004). In this study these two factors are separated since each include a wide range of parameters. Another feature of the social reconstructionist tradition "is its democratic and emancipatory impulse and the focus of teachers' deliberations on issues that help them examine the social and political consequences of their teaching" (Zeichner \& Liston, 1996, p. 59). Such elements and the related items have been grouped under the category of 'critical' factor in the instrument developed in this study.

\subsection{Focus on moral/ethical parameters}

Undoubtedly moral aspects play a crucial role in the teaching practice (Hansen, 1998; Johnson \& Reiman, 2007). When it comes to morality, and when it comes to reflection, according to Meiers (2003), "Reflective teaching is not done to students. Rather, it directly engages them as participants and co-authors of a shared project - the educational, social, and moral life of their classroom" (p. 1). Hansen (1998) refers to Valli's (1990) three strands of reflection which take into account the notion of morality. The 'deliberative approach' "urges teachers to think critically about their purposes and how to justify them from a moral point of view" (Hansen, 1998, p. 644). The second approach called the 'relational approach' "draws upon moral philosophy and feminist theory which centers the moral life around issues of personal character and how individuals regard and treat other individuals" (p. 645). The third approach called the 'critical approach' is, according to Hansen (1998), very much similar to critical reflection and is also accentuated by Adler and Goodman, Apple, and Giroux and McLaren. Within this approach, as Hansen (1998) puts it:

Teachers are under a moral obligation to advance the rights of the least advantaged in society, and to resist or subvert any institutional or political agendas that impede that advance. Teachers should assist students in deconstructing dominant social ideologies and in learning to claim a voice of their own. The moral significance of teaching, in this framework, boils down to the requirement to help change institutional structures and configurations (p. 645). 
Hansen criticizes these approaches believing that there is no need to refer to the outside of the classroom to seek for some fixed moral rules. He believes that "The moral is in the practice... Teaching means attending to students, listening to them, identifying their strengths and weaknesses with an eye on supporting the former and overcoming the latter, and more" (p. 653). Hansen's point of view, however, takes into account some of the parameters in those three approaches, but it looks at the teaching practice as a moral enterprise in the sense that the morals of the classroom teaching emerge as the practice is going on. What matters here is that reflective teaching cannot develop unless reflective practitioners pay due attention to the moral aspects of their teaching. Items dealing with this aspect are grouped under the 'moral factor' in the instrument developed in this study.

Although some overlap among the different factors and components of reflection is evident, between 'cognitive' and 'practical,' or between 'critical' and 'moral' for instance, the researcher, after comparing the results of the content analysis of the interviews carried out in the qualitative part of the study with the item pool developed from the literature, came up with six crucial and necessary factors and components dominating the conception of reflection. The items constructed for the item pool all indicate a reflective behaviour based on the supportive literature and the interviews.

\section{Conclusion}

Reflective teaching has been introduced to ELT community as a result of the shift of paradigm from positivist-oriented perspective to a constructivist-oriented one and it gained momentum after the demise of method and in "beyond method" era. Apart from some potential flaws and pitfalls, reflective teaching provides ELT practitioners and language teachers with a variety of techniques to become more conscious of their own actions and feelings in and outside the classrooms. And as Akbari (2007) puts it "it is good to reflect, but reflection itself also requires reflection."

\section{References}

Akbari, R. (2005). Recent Developments in Foreign Language Teaching. ROSHD FLT, 20, 76, 25-32.

Akbari, R. (2007). Reflections on reflection: A critical appraisal of reflective practices in L2 teacher education. System, (35):2, 192-207.

Apple, M. W., \& Teitelbaum, K. (2001). John Dewey. In J. A. Palmer. (Ed.), Fifty Major Thinkers on Education: From Confucius to Dewey (pp. 177-182). London: Routledge.

Bartlett, L. (1997). Teacher development through reflective teaching. In J.C. Richards, and D. Nunan. (Eds.), Second Language Teacher Education (pp. 202-214). New York: Cambridge University Press.

Brown, H. D. (2000). Principles of Language Learning and Teaching. New York: Longman.

Clarke, M. A. (1994). The Dysfunctions of the Theory/Practice Discourse. TESOL Quarterly, (28):1, 10-27.

Clarke, M., \& Otaky, D. (2006). Reflection 'on' and 'in' teacher education in the United Arab Emirates. International Journal of Educational Development, 26, 111-122. doi:10.1016/j.ijedudev.2005.07.018, http://dx.doi.org/10.1016/j.ijedudev.2005.07.018

Cornford, I. (2002). Reflective teaching: Empirical research findings and some implications for teacher education. Journal of Vocational Education and Training, 54, 2, 219-235. doi:10.1080/13636820200200196, http://dx.doi.org/10.1080/13636820200200196

Crandall, J. A. (2000). Language teacher education. Annual Review of Applied Linguistics, 20, 34-55. doi:10.1017/S0267190500200032, http://dx.doi.org/10.1017/S0267190500200032

Cunningham, F. M. (2001). Reflecting Teaching Practice in Adult ESL Settings. ERIC Digest, 1-7.

El-Dib, M. A. B. (2007). Levels of reflection in action research. An overview and an assessment tool. Teaching and Teacher Education, 23, 24-35. doi:10.1016/j.tate.2006.04.002, http://dx.doi.org/10.1016/j.tate.2006.04.002

Farrell, T. (1998). Reflective Teaching: The Principles and Practices. English Teaching Forum, 10-17.

Farrell, T. (1999a). Reflective practice in an EFL teacher development group. System, 27, 157-172. doi:10.1016/S0346-251X(99)00014-7, http://dx.doi.org/10.1016/S0346-251X(99)00014-7

Farrell, T. (1999b). Teachers talking about teaching: Creating conditions for reflection. TESL-EJ, (4)2:1-15.

Farrell, T. (2001). Tailoring Reflection to Individual Needs: a TESOL Case Study. Journal of Education for Teaching, (27)1:23-38. doi:10.1080/02607470120042528, http://dx.doi.org/10.1080/02607470120042528

Farrell, T. (2004). Reflective Practice in Action: 80 Reflection Breaks for Busy Teachers. California: Corwin Press. 
Fendler, L. (2003). Teacher Reflection in a Hall of Mirrors: Historical Influences and Political Reverberations. Educational Researcher, (32)3:16-25. doi:10.3102/0013189X032003016, http://dx.doi.org/10.3102/0013189X032003016

Freeman, D. (2002). The hidden side of the work: Teacher knowledge and learning to teach. Lang. Teach., 35, 1-13. doi:10.1017/S0261444801001720, http://dx.doi.org/10.1017/S0261444801001720

Freese, A. R. (1999). The role of reflection on preservice teachers' development in the context of a professional development school. Teaching and Teacher Education, 15, 895-909. doi:10.1016/S0742-051X(99)00029-3, http://dx.doi.org/10.1016/S0742-051X(99)00029-3

Gebhard, J. G. (2005). Teacher Development through Exploration: Principles, Ways, and Examples. TESL-EJ, (9)2:1-15.

Gimenez, T. (1999). Reflective Teaching and Teacher Education Contributions from Teacher Training. Linguagem \& Ensino, (2)2:129-143.

Griffiths, V. (2000). The reflective dimension in teacher education. International Journal of Educational Research, 33, 539-555. doi:10.1016/S0883-0355(00)00033-1, http://dx.doi.org/10.1016/S0883-0355(00)00033-1

Hansen, D. T. (1998). The Moral is in the Practice. Teaching and Teacher Education, (14)6:653-655.

Hillier, Y. (2005). Reflective Teaching in Further and Adult Education. London: Continuum.

Ixer, G. (1999). There's No Such Thing As Reflection. British Association of Social Workers, 29, 513-527.

Jackson, M. (2006). In M. Jackson, D. D. Ignatavicius, \& B. Case. (Eds.), Critical Thinking and Clinical Judgment (pp. 3-17). London: Jones and Bartlett Publishers, Inc.

Jay, J. K., \& Johnson, K. L. (2002). Capturing complexity: a typology of reflective practice for teacher education. Teaching and Teacher Education, 18, 73-85. doi:10.1016/S0742-051X(01)00051-8, http://dx.doi.org/10.1016/S0742-051X(01)00051-8

Johnson, K., \& Johnson, H. (1999). Encyclopedic Dictionary of Applied Linguistics. Oxford: Blackwell Publishers.

Johnson, L. E., \& Reiman, A. J. (2007). Beginning Teacher Disposition: Examining the Moral/Ethical Domain. Teaching and Teacher Education, 23, 676-687. doi:10.1016/j.tate.2006.12.006, http://dx.doi.org/10.1016/j.tate.2006.12.006

Johnstone, R. (2006). Language Teacher Education, In A. Davies, \& C. Elder. (Eds.), The Handbook of Applied Linguistics (pp. 649-671). Oxford: Blackwell Publishing Ltd.

Korthagen, F. A. J., \& Wubbels, T. (1995). Characteristics of reflective practitioners: towards an operationalization of the concept of reflection. Teachers and Teaching, (1)1:51-72. doi:10.1080/1354060950010105, http://dx.doi.org/10.1080/1354060950010105

Kumaravadivelu, B. (1994). The Postmethod Condition: (E)merging Strategies for Second/Foreign Language Teaching. TESOL Quarterly, (28)1:27-48. doi:10.2307/3587197, http://dx.doi.org/10.2307/3587197

Kumaravadivelu, B. (2001). Toward a Postmethod Pedagogy. TESOL Quarterly, (35)4:537-560. doi:10.2307/3588427, http://dx.doi.org/10.2307/3588427

Kumaravadivelu, B. (2003a). Critical Language Pedagogy: A Postmethod Perspective on English Language Teaching. World Englishes, (22)4:539-550. doi:10.1111/j.1467-971X.2003.00317.x, http://dx.doi.org/10.1111/j.1467-971X.2003.00317.x

Kumaravadivelu, B. (2003b). Beyond Methods: Macrostrategies for Language Teaching. New Haven, C. T.: Yale University Press.

Kumaravadivelu, B. (2005). In Defense of Postmethod. ILI Language Teaching Journal, (1)1:15-19.

LaBoskey, V. K. (1997). Teaching to Teach with Purpose and Passion: Pedagogy for Reflective Practice. In J. Loughran, \& T. Russell. (Eds.), Teaching about Teaching: Purpose, Passion and Pedagogy in Teacher Education (pp. 150-163). London: Falmer Press.

Loughran, J. J. (2002). Effective Reflective Practice: In Search of Meaning in Learning about Teaching. Journal of Teacher Education, 53, 1, 33-43. doi:10.1177/0022487102053001004, http://dx.doi.org/10.1177/0022487102053001004

Meiers, M. (2003). Reflective Teaching Builds Learning Communities. Teaching Today for Tomorrow, 1-7. 
Murphy, J. M. (2001). Reflective Teaching in ELT. In M. Celce-Murcia. (Ed.), Teaching English as a Second or Foreign Language (pp. 499-514). Boston: Heinle \& Heinle.

Osterman, K. F., \& Kottkamp, R. B. (2004). Reflective Practice for Educators. California: Corwin Press.

Pacheco, A. Q. (2005). Reflective Teaching and its Impact on Foreign Language Teaching. Numero Extraordinario, 5, 1-19.

Parker, S. (1997). Reflective Teaching in the Postmodern World: a manifesto for education in postmodernity. Buckingham: Open University Press.

Pennycook, A. (1989). The Concept of Method, Interested Knowledge, and the Politics of Language Teaching. TESOL Quarterly, (23)4:589-612. doi:10.2307/3587534, http://dx.doi.org/10.2307/3587534

Pica, T. (2000). Tradition and transition in English language teaching methodology. System, 28, 1-18. doi:10.1016/S0346-251X(99)00057-3, http://dx.doi.org/10.1016/S0346-251X(99)00057-3

Pollard, A. (Ed.). (2002). Readings for Reflective Teaching. London: Continuum.

Pollard, A. et al. (2006). Reflective Teaching. London: Continuum.

Prabhu, N. S. (1990). There Is No Best Method-Why? TESOL Quarterly, (24)2:161-176. doi:10.2307/3586897, http://dx.doi.org/10.2307/3586897

Reed, Y., Davis, H., \& Nyabanyaba, T. (2002). Investigating Teachers' 'Take-up' of Reflective Practice from an In-service Professional Development Teacher Education Programme in South Africa. Educational Action Research, (10)2:253-274. doi:10.1080/09650790200200185, http://dx.doi.org/10.1080/09650790200200185

Richards, J. C. (2000). Beyond training. Cambridge: Cambridge University Press.

Richards, J. C. \& Lockhart, C. (1999). Reflective teaching in second language classrooms. New York: Cambridge University Press.

Richards, J. C., \& Rodgers, T. S. (2002). Approaches and Methods in Language Teaching. Cambridge: Cambridge University Press.

Richards, J. C., \& Schmidt, R. (2002). Longman Dictionary of Language Teaching and Applied Linguistics. London: Pearson Education.

Richards, J. C., \& Farrell, T. (2005). Professional Development for Language Teachers. New York: Cambridge University Press.

Stanley, C. (1998). A Framework for Teacher Reflectivity. TESOL Quarterly, (32)3:584-591. doi:10.2307/3588129, http://dx.doi.org/10.2307/3588129

Tabachnik, R., \& Zeichner, K. (2002). Reflections on Reflective Teaching. In A. Pollard. (Ed.), Readings for Reflective Teaching (pp. 13-16). London: Continuum.

Thiessen, D. (2000). A skillful start to a teaching career: a matter of developing impactful behaviors, reflective practices, or professional knowledge? International Journal of Educational Research, 33, 515-537. doi:10.1016/S0883-0355(00)00032-X, http://dx.doi.org/10.1016/S0883-0355(00)00032-X

Tsui, A. B. M. (2003). Understanding expertise in teaching: Case studies of ESL teachers. New York: Cambridge University Press.

Vieira, F., \& Marquez, I. (2002). Supervising Reflective Teacher Development Practices. ELTED, 6, 1-18.

Widdowson, H. G. (1990). Aspects of Language Teaching. Oxford: Oxford University Press.

Zeichner, K. M., \& Liston, D. P. (1996). Reflective teaching: An Introduction. New Jersey: Lawrence Erlbaum Associates, Inc., Publishers. 